\title{
Differentiation Among Mycobacterial Species by Thin-Layer Chromatography
}

\author{
M. TSUKAMURA AND S. MIZUNO \\ National Sanatorium Chubu Chest Hospital, Obu, Aichi, Japan 474
}

\begin{abstract}
Thin-layer chromatography of the ethyl ether-ethanol-soluble fraction after incubation with $\left[{ }^{35} \mathrm{~S}\right]$ methionine is useful for differentiation among mycobacterial species. Scanning of the radioactivity on chromatograms showed various distribution patterns of radioactive spots, and the patterns were, in most cases, characteristic for the species.
\end{abstract}

Analysis of lipid composition is known as a useful tool for differentiating mycobacterial species $(9,10,13,14,16,17,21,22,24,33)$. Radioisotope techniques have not yet been used for differentiation of mycobacteria, except by Tsukamura et al. (31), who measured the uptake of $\left.{ }^{35} \mathrm{~S}\right]$ methionine in various mycobacteria. They measured the radioactivity of whole cells after incubation with ${ }^{35} \mathrm{~S}$ /methionine and observed that pathogenic group III mycobacteria (Mycobacterium avium and $M$. intracellulare) and $M$. tuberculosis and $M$. bovis showed significantly lower activity than the other mycobacteria. The present study was designed to develop the previous method into a more reliable one.

\section{MATERIALS AND METHODS}

The strains used are listed in Table 1. Most of the strains were identified through cooperative studies of the International Working Group on Mycobacterial Taxonomy (IWGMT) $(11,18,35)$. Some strains were identified in this laboratory by methods described previously $(29,30)$. The organisms were grown in Ogawa egg medium at $37 \mathrm{C}$ for 5 days (rapidly growing mycobacteria, $M$. phlei through $M$. flavescens in Table 1 ) or 14 days (slowly growing mycobacteria, $M$. kansasii through $M$. gordonae in Table 1). The cells were washed three times in saline and then weighed; $100-\mathrm{mg}$ amounts (wet weight) of the cells were suspended in $2.0 \mathrm{ml}$ of $0.067 \mathrm{M}$ phosphate buffer solution ( $\mathrm{pH} 7.1$ ) containing $5 \mu \mathrm{Ci}$ of $\mathrm{L}-\left[{ }^{35} \mathrm{~S}\right]$ methionine and $10 \mu \mathrm{g}$ of sodium acetate per $\mathrm{ml}$. The tubes containing the mixture were stoppered with cotton plugs and incubated at $37 \mathrm{C}$ for $20 \mathrm{~h}$. After incubation, the cells were centrifuged at $500 \times g$ for $15 \mathrm{~min}$ and washed twice with $5.0 \mathrm{ml}$ of chilled water. The cells were extracted twice with $2.0 \mathrm{ml}$ of $10 \%$ trichloroacetic acid, each for $10 \mathrm{~min}$. The acid extracts were separated from the cells by centrifugation and discarded. The cells were then extracted twice with 3.0 $\mathrm{ml}$ of ethyl ether-ethanol $(1: 1, \mathrm{vol} / \mathrm{vol})$ for $10 \mathrm{~min}$ each. During the first $5 \mathrm{~min}$ of the extraction, the cells were mixed continuously with a glass stick at room temperature $(25 \pm 3 \mathrm{C})$; during the second $5 \mathrm{~min}$, the tubes were allowed to stand in an incubator at $37 \mathrm{C}$, during which time the cells sedimented. The extracts could then be separated easily by means of a pipette. The combined ethyl ether-ethanol-soluble fractions were labeled as "lipid fraction." The residue was dissolved in $2.0 \mathrm{ml}$ of a $1 \% \mathrm{NaOH}$ solution by heating at $100 \mathrm{C}$ in a water bath for $5 \mathrm{~min}$.

L- $\left.{ }^{35} \mathrm{~S}\right]$ methionine was a product of New England Nuclear Corp., Boston, Mass. (specific activity, 264 $\mathrm{Ci} / \mathrm{mmol}$; radiochemical purity, $>93 \%$; containing $<7.0 \%$ methionine sulfoxide, $<0.2 \%$ methionine sulfone, and $<0.2 \%$ homocysteic acid). Ethyl ether was a product of Katayama Chemical Company, Osaka, Japan (specific gravity, below 0.720; fraction [34 to $35 \mathrm{C}$ ], minimum $95 \%$ [by volume]; water, maximum $0.3 \%$; nonvolatile, maximum $0.002 \%$; acidity $\left[\mathrm{CH}_{3} \mathrm{COOH}\right]$, maximum $0.003 \%$ ). Ethyl alcohol also was a product of Katayama Chemical Company, Osaka, Japan (bp, $78 \mathrm{C}$; specific gravity, below 0.797 ; nonvolatile, maximum $0.003 \%$; acidity $\left[\mathrm{CH}_{3} \mathrm{COOH}\right]$, maximum $0.003 \%$; heavy metals $[\mathrm{Pb}]$, maximum $0.0002 \%$; ketones $\left[\mathrm{CH}_{3} \cdot \mathrm{CO} \cdot \mathrm{CH}_{3}\right]$, maximum $0.002 \%$; assay by specific gravity, minimum $99.46 \%$ by volume]). Samples, each $0.2 \mathrm{ml}$, were taken from the lipid fraction and the residue fraction.

The samples were placed in stainless-steel planchets and dried by heating with an infrared lamp. The radioactivity of each sample was measured by a gas flow counter. The samples of the lipid fraction and the residue fraction contained the radioactivity from 3.3 $\mathrm{mg}$ (wet weight) and $10 \mathrm{mg}$ (wet weight) of the cells, respectively.

After the sample was taken for measurement of radioactivity, the remaining lipid fraction was concentrated to $0.1 \mathrm{ml}$ under reduced pressure at room temperature, and the concentrate was subjected to thin-layer chromatography (TLC).

Silica Gel $\mathrm{H}$ was used according to Stahl (Kieselgel H nach Stahl, Art 7736, E. Merck, Darmstadt, Germany). Gel $(30 \mathrm{~g})$ was shaken with $70 \mathrm{ml}$ of distilled water in a $150-\mathrm{ml}$ stoppered flask for $60 \mathrm{~s}$. This mixture was spread on glass sheets. Gel layers ( 20 by $20 \mathrm{~cm} ; 0.25 \mathrm{~mm}$ thick) were prepared and dried for $30 \mathrm{~min}$ at $110 \mathrm{C}$ in a hot-air oven. The gel layers were cleaned by an acetone run and activated at $120 \mathrm{C}$ for $30 \mathrm{~min}$. The samples were placed, with a micropipette, on the layer at intervals of $4 \mathrm{~cm}$. The 
TABLE 1. List of strains ${ }^{a}$

\begin{tabular}{|c|c|c|c|}
\hline Species/reference & $\begin{array}{c}\text { Strain } \\
\text { no. }\end{array}$ & $\begin{array}{l}\text { Strain no. } \\
\text { received }\end{array}$ & Source \\
\hline M. kansasii Hauduroy 1955 (8) & $\begin{array}{l}07001 \\
07002 \\
07008\end{array}$ & $\begin{array}{l}\text { Forbes }-84 \\
\text { Bostrum D35 } \\
\text { P-18 }\end{array}$ & $\begin{array}{l}\text { K. Takeya; E.H. Runyon } \\
\text { K. Takeya; E.H. Runyon } \\
\text { K. Takeya; E.H. Runyon }\end{array}$ \\
\hline M. marinum Aronson 1926 (1) & $\begin{array}{l}08002 \\
08003 \\
08010\end{array}$ & $\begin{array}{l}\text { B-916 } \\
\text { B-913 } \\
\text { ATCC } 927\end{array}$ & $\begin{array}{l}\text { K. Konno; A.J. Ross } \\
\text { K. Konno; A.J. Ross } \\
\text { ATCC }\end{array}$ \\
\hline M. avium Chester 1901 (6) & $\begin{array}{l}11016 \\
11017 \\
11020\end{array}$ & $\begin{array}{l}\text { ATCC } 15769 \\
\text { ATCC } 19075 \\
\text { ATCC } 15773\end{array}$ & $\begin{array}{l}\text { ATCC } \\
\text { ATCC } \\
\text { ATCC }\end{array}$ \\
\hline M. intracellulare Runyon 1967 (20) & $\begin{array}{l}13001 \\
13082 \\
13083\end{array}$ & $\begin{array}{l}\text { P.40 } \\
\text { ATCC } 19077 \\
\text { ATCC } 19178\end{array}$ & $\begin{array}{l}\text { K. Takeya; E.H. Runyon } \\
\text { ATCC } \\
\text { ATCC }\end{array}$ \\
\hline $\begin{array}{l}\text { M. nonchromogenicum Tsukamura } \\
1965(25)\end{array}$ & $\begin{array}{l}09003 \\
09023 \\
09033\end{array}$ & $\begin{array}{l}\text { ATCC } 19530 \\
\text { ATCC } 19532 \\
\text { ATCC } 19533\end{array}$ & $\begin{array}{l}\text { ATCC; Tsukamura } 317 \\
\text { ATCC; Tsukamura } 1721 \\
\text { ATCC; Tsukamura } 1731\end{array}$ \\
\hline M. terrae Wayne 1966 (34) & $\begin{array}{l}38001 \\
38002 \\
38013\end{array}$ & $\begin{array}{l}\text { W-167 } \\
\text { W-168A } \\
\text { ATCC } 15755\end{array}$ & $\begin{array}{l}\text { L.G. Wayne } \\
\text { L. G. Wayne } \\
\text { ATCC; Wayne W-45 }\end{array}$ \\
\hline M. novum Tsukamura 1967 (27) & $\begin{array}{l}24018 \\
24021 \\
24022\end{array}$ & $\begin{array}{l}\text { ATCC } 19619 \\
\text { ATCC } 19621 \\
\text { ATCC } 19622\end{array}$ & $\begin{array}{l}\text { ATCC; Tsukamura } 1945 \\
\text { ATCC; Tsukamura } 1952 \\
\text { ATCC; Tsukamura } 1954\end{array}$ \\
\hline M. triviale Kubica 1970 (12) & $\begin{array}{l}37003 \\
37004 \\
37013\end{array}$ & $\begin{array}{l}\text { C1614 } \\
\text { C5181 } \\
\text { T254-3 }\end{array}$ & $\begin{array}{l}\text { G.P. Kubica } \\
\text { G.P. Kubica } \\
\text { G.P. Kubica }\end{array}$ \\
\hline $\begin{array}{l}\text { M. marianum (M. scrofulaceum) Suzanne } \\
\text { and Penso } 1953(23)\end{array}$ & $\begin{array}{l}12002 \\
12107 \\
12108\end{array}$ & $\begin{array}{l}\text { P-6 } \\
\text { ATCC } 15978 \\
\text { ATCC } 19073\end{array}$ & $\begin{array}{l}\text { K. Takeya; E.H. Runyon } \\
\text { ATCC } \\
\text { ATCC }\end{array}$ \\
\hline M. gordonae Bojalil et al. 1962 (3) & $\begin{array}{l}\mathrm{T}-12109 \\
\mathrm{~T}-12110 \\
\mathrm{~T}-12177\end{array}$ & $\begin{array}{l}\text { ATCC } 14470 \\
\text { ATCC } 19277 \\
\text { ATCC } 23283\end{array}$ & $\begin{array}{l}\text { ATCC } \\
\text { ATCC } \\
\text { ATCC }\end{array}$ \\
\hline $\begin{array}{l}\text { M. phlei Lehmann and Neumann } 1899 \\
\text { (15) }\end{array}$ & $\begin{array}{l}14001 \\
\\
14002 \\
14003 \\
14004 \\
14022\end{array}$ & $\begin{array}{l}\text { SN101 } \\
\text { SN102 } \\
\text { SN103 } \\
\text { SN104 } \\
\text { ATCC } 19249\end{array}$ & $\begin{array}{l}\text { R. Bönicke } \\
\text { R. Bönicke } \\
\text { R. Bönicke } \\
\text { R. Bönicke } \\
\text { ATCC }\end{array}$ \\
\hline $\begin{array}{l}\text { M. smegmatis Lehmann \& Neumann } \\
1899 \text { (15) }\end{array}$ & $\begin{array}{l}17001 \\
17002 \\
17003\end{array}$ & $\begin{array}{l}\text { SN1 } \\
\text { SN2 } \\
\text { SN3 }\end{array}$ & $\begin{array}{l}\text { R. Bönicke } \\
\text { R. Bönicke } \\
\text { R. Bönicke }\end{array}$ \\
\hline
\end{tabular}

${ }^{a}$ R. Bönicke, Forschungsinstitut Borstel, 2061 Borstel, West Germany. G. P. Kubica, Trudeau Institute, Saranac Lake, N.Y., USA. K. Konno, Tohoku University, Sendai, Japan. K. Takeya, Kyushu University, Fukuoka, Japan. L. G. Wayne, Veterans Administration Hospital, Long Beach, Calif., USA. NCTC, National Collection of Type Cultures, Central Public Health Laboratory, London, England. ATCC, American Type Culture Collection, Rockville, Md., USA. 
TABLE 1-Continued

\begin{tabular}{|c|c|c|c|}
\hline Species/reference & $\begin{array}{c}\text { Strain } \\
\text { no. }\end{array}$ & $\begin{array}{l}\text { Strain no. } \\
\text { received }\end{array}$ & Source \\
\hline & $\begin{array}{l}17004 \\
17027\end{array}$ & $\begin{array}{l}\text { SN4 } \\
\text { ATCC } 14468\end{array}$ & $\begin{array}{l}\text { R. Bönicke } \\
\text { ATCC }\end{array}$ \\
\hline \multirow[t]{5}{*}{ M. vaccae Bönicke and Juhasz 1964 (4) } & 21007 & ATCC 15483 & ATCC \\
\hline & 21008 & ATCC 23002 & ATCC \\
\hline & 21009 & ATCC 23004 & ATCC \\
\hline & 21010 & ATCC 23005 & ATCC \\
\hline & 21011 & ATCC 23014 & ATCC \\
\hline \multirow[t]{5}{*}{ M. aurum Tsukamura 1966 (26) } & 15001 & NCTC 10439 & NCTC; Tsukamura 303 \\
\hline & 15003 & Exp 327 & M. Tsukamura \\
\hline & 15005 & Exp 352 & M. Tsukamura \\
\hline & 15006 & ATCC 23366 & ATCC; Tsukamura 358 \\
\hline & 15011 & NCTC 10438 & NCTC; Tsukamura 312 \\
\hline \multirow{5}{*}{$\begin{array}{l}\text { M. thermoresistibile Tsukamura } 1966 \\
\text { (26) }\end{array}$} & 01002 & ATCC 19528 & ATCC; Tsukamura 1002 \\
\hline & 01028 & ATCC 19529 & ATCC; Tsukamura 1028 \\
\hline & 01029 & $\exp .1029$ & M. Tsukamura \\
\hline & 01030 & exp. 1030 & M. Tsukamura \\
\hline & 01039 & ATCC 19527 & ATCC; Tsukamura 316 \\
\hline \multirow[t]{5}{*}{ M. fortuitum Da Costa Cruz 1938 (7) } & 18001 & ATCC 19709 & ATCC; Tsukamura 335 \\
\hline & 18008 & ATCC 6841 & ATCC; J. Da Costa Cruz \\
\hline & 18009 & NCTC 8697 & NCTC \\
\hline & 18109 & ATCC 6842 & ATCC; J. Da Costa Cruz \\
\hline & 18110 & ATCC 14467 & ATCC \\
\hline \multirow{5}{*}{$\begin{array}{l}\text { M. chelonei subsp. chelonei Bergey et } \\
\quad \text { al. } 1923(2)\end{array}$} & 19001 & SN 281 & R. Bönicke \\
\hline & 19002 & SN 282 & R. Bönicke \\
\hline & 19003 & SN 283 & R. Bönicke \\
\hline & 19009 & ATCC 19235 & ATCC; R. Bönicke \\
\hline & 19010 & ATCC 19237 & ATCC; R. Bönicke \\
\hline \multirow{5}{*}{$\begin{array}{l}\text { M. chelonei subsp. abscessus Moore } \\
\text { and Frerichs } 1953(19)\end{array}$} & 22011 & ATCC 14472 & ATCC \\
\hline & 22012 & ATCC 19977 & ATCC \\
\hline & 22013 & ATCC 23006 & ATCC \\
\hline & 22014 & ATCC 23007 & ATCC \\
\hline & 22015 & ATCC 23016 & ATCC \\
\hline \multirow[t]{5}{*}{ M. chitae Tsukamura 1967 (28) } & 31001 & NCTC 10485 & NCTC; M. Tsukamura \\
\hline & 31003 & ATCC 19628 & ATCC; M. Tsukamura \\
\hline & 31004 & ATCC 19629 & ATCC; M. Tsukamura \\
\hline & 31005 & ATCC 19630 & ATCC; M. Tsukamura \\
\hline & 31008 & ATCC 19627 & ATCC; M. Tsukamura \\
\hline \multirow[t]{5}{*}{ M. flavescens Bojalil et al. 1962 (3) } & 33001 & ATCC 14474 & ATCC \\
\hline & 33002 & Expt 3362 & M. Tsukamura \\
\hline & 33003 & Expt 3363 & M. Tsukamura \\
\hline & 33004 & Expt 3364 & M. Tsukamura \\
\hline & 33005 & Expt 3365 & M. Tsukamura \\
\hline
\end{tabular}

following developing solvent was used in $13-$ to $14-\mathrm{cm}$ unidimensional runs: $n$-propanol-n-butanol-waterammonia $(57: 20: 20: 3, \mathrm{vol} / \mathrm{vol} / \mathrm{vol} / \mathrm{vol})$. Developed chromatograms were dried at $100 \mathrm{C}$ for $30 \mathrm{~min}$ and then subjected to scanning of the radioactivity by an automatic TLC scanner (Nihon-Musen Co., Tokyo,
Japan) (slit, 6 by $30 \mathrm{~mm}$; range, 1,000 counts $/ 5 \mathrm{~s}$; chart speed, $300 \mathrm{~mm} / \mathrm{h}$; recording speed, $150 \mathrm{~mm} / \mathrm{h}$ ).

\section{RESULTS}

Distribution of the radioactivity into the lipid fraction (ethyl ether-ethanol-soluble 
fraction) and residue fraction. Among the slowly growing mycobacterial species tested, the radioactivity of the lipid fraction was significantly lower in $M$. avium and $M$. intracellulare than in other species (Table 2). Among the rapidly growing mycobacteria tested, $M$. smegmat is and $M$. chelonei showed the lowest radioactivity in their lipid fraction, $M$. vaccae and $M$. chitae showed the highest, and the others were intermediate. In contrast to the above, the radioactivity in the residue fraction did not differ significantly among various species and was much greater than that in the lipid fractions (Table 2). $M$. avium seemed, exceptionally, to show low radioactivity in the residue fraction also.

TLC of the ethyl ether-ethanol-soluble fraction (lipid fraction). The results of the TLC method of investigation are summarized in $\mathrm{Ta}$ ble 3 and illustrated in Fig. 1-7. Thin-layer chromatograms of the lipid fractions obtained from cultures of $M$. nonchromogenicum strain 09003, one 7 days old, one 14 days old, and one 21 days old, and from cultures of $M$. chitae strain 31003 , one 3 days old, one 7 days old, and one 14 days old, are shown in Fig. 1. The results suggest that the distribution pattern of radioactive spots is not greatly influenced by the cultivation period of the test organisms but that the organisms obtained from old cultures tended to show lower activity. In view of these results, the cultivation periods of 14 and 5 days were used in slowly growing and rapidly growing mycobacteria, respectively. Strains belonging to the same species showed similar patterns. The results for $M$. nonchromogenicum, $M$. avium, and $M$. thermoresistibile are shown as examples in Fig. 2 and 3 . All three strains of $M$. avium and all three strains of $M$. thermoresistibile showed the same pattern (Fig. 2 and 3). On the other hand, two strains of $M$. nonchromogenicum showed the same pattern, but one strain showed a slightly different pattern, lacking a spot (Fig. 2).

All three strains of $M$. kansasii and all three strains of $M$. marinum showed the same patterns, one of each of which is illustrated in Fig. 4 . These two photochromogens were differentiated clearly by the pattern.

Strains of the species of group II seemed to be heterogenous as to pattern. Of two strains (12008 and 12107) of $M$. marianum (synonym $M$. scrofulaceum), the latter strain lacked two spots that the former showed (Fig. 4). Another strain (12002) had the same pattern as that of strain 12008. Three strains of $M$. gordonae showed slightly different patterns (Table 3 ).

TABLE 2. Distribution of the radioactivity into ethyl ether-ethanol-soluble and residue fractions

\begin{tabular}{|c|c|c|c|}
\hline \multirow[b]{2}{*}{ Species } & \multirow{2}{*}{$\begin{array}{l}\text { No. of } \\
\text { strains }\end{array}$} & \multicolumn{2}{|c|}{ Radioactivity (counts $/ \mathrm{min})^{a}$} \\
\hline & & $\begin{array}{l}\text { Ethyl ether-ethanol-soluble } \\
\text { fraction }(\times 30)\end{array}$ & $\begin{array}{l}\text { Residue fraction } \\
\qquad(\times 10)\end{array}$ \\
\hline $\begin{array}{l}M . \text { kansasii } \\
M . \text { marinum } \\
M . \text { avium } \\
M . \text { intracellulare } \\
M . \text { nonchromogenicum } \\
M . \text { terrae } \\
M . \text { novum } \\
M . \text { triviale } \\
M . \text { marianum (M. scrofulaceum) } \\
M . \text { gordonae } \\
M . \text { phlei } \\
M . \text { smegmatis } \\
M . \text { vaccae } \\
M . \text { aurum } \\
M . \text { thermoresistibile } \\
M . \text { fortuitum } \\
M . \text { chelonei } \text { subsp. chelonei } \\
M . \text { chelonei subsp. abscessus } \\
M . \text { chitae } \\
M . \text { flavescens }\end{array}$ & $\begin{array}{l}3 \\
3 \\
3 \\
3 \\
3 \\
3 \\
3 \\
3 \\
3 \\
3 \\
5 \\
5 \\
5 \\
5 \\
5 \\
5 \\
5 \\
5 \\
5 \\
5\end{array}$ & $\begin{aligned} 402 & \pm 142 \\
874 & \pm 254 \\
158 & \pm 63 \\
149 & \pm 23 \\
1,379 & \pm 702 \\
366 & \pm 164 \\
893 & \pm 625 \\
299 & \pm 160 \\
512 & \pm 25 \\
640 & \pm 601 \\
1,077 & \pm 521 \\
540 & \pm 179 \\
3,850 & \pm 1,199 \\
1,880 & \pm 698 \\
1,930 & \pm 1,211 \\
1,087 & \pm 523 \\
426 & \pm 151 \\
696 & \pm 273 \\
3,768 & \pm 1,416 \\
968 & \pm 415\end{aligned}$ & $\begin{aligned} 17,280 & \pm 3,272 \\
22,151 & \pm 7,329 \\
9,637 & \pm 5,348 \\
17,606 & \pm 3,541 \\
23,214 & \pm 6,338 \\
14,945 & \pm 2,863 \\
23,539 & \pm 4,827 \\
23,613 & \pm 1,762 \\
15,972 & \pm 1,768 \\
27,285 & \pm 1,109 \\
26,510 & \pm 2,221 \\
30,506 & \pm 1,280 \\
28,370 & \pm 4,387 \\
32,621 & \pm 4,705 \\
21,980 & \pm 4,654 \\
34,552 & \pm 2,798 \\
25,109 & \pm 4,315 \\
24,500 & \pm 6,172 \\
31,822 & \pm 1,168 \\
29,718 & \pm 2,618\end{aligned}$ \\
\hline
\end{tabular}

${ }^{a}$ (Mean in three or five strains) \pm (standard deviation). The radioactivity shows the activity measured in a $0.2-\mathrm{ml}$ sample. Since the amounts of ethyl ether-ethanol-soluble and residue fractions were 6.0 and $2.0 \mathrm{ml}$, respectively, the total radioactivity in the fraction can be obtained by multiplying the counts per minute by 30 and 10 , respectively. 
TABLE 3. Radioactive spots in thin-layer chromatograms of ethyl ether-ethanol-soluble fraction (lipid fraction) ${ }^{a}$

\begin{tabular}{|c|c|c|c|c|c|}
\hline \multirow{2}{*}{ Species } & \multicolumn{5}{|c|}{ Radioactive spots } \\
\hline & a & b & $\mathrm{c}$ & d & e \\
\hline M. kansasii & a & b & c & & $\mathbf{E}$ \\
\hline M. marinum & a & $\mathrm{b}$ & $\mathrm{c}$ & & \\
\hline M. avium & & & & & $\mathbf{E}$ \\
\hline$M$. intracellulare & & & & & $\mathrm{E}^{*}$ \\
\hline M. nonchromogenicum & & $b$ & $\mathrm{c}$ & $d^{*}$ & $\mathrm{E}$ \\
\hline M. terrae & a & b & c & & \\
\hline$M$. novum & $a^{*}$ & b & c & $d^{*}$ & \\
\hline M. triviale & a & $\mathrm{b}$ & c & & \\
\hline $\begin{array}{l}\text { M. marianum } \\
(M . \text { scrofulaceum })\end{array}$ & a & $b^{*}$ & $c^{*}$ & & \\
\hline$M$. gordonae & a & b & $\mathrm{c}^{*}$ & & $\mathrm{e}^{*}$ \\
\hline M.phlei & $A^{*}$ & B & $\mathrm{c}$ & & e \\
\hline M. smegmatis & a & & & & $\mathrm{E}$ \\
\hline M.vaccae & & B & $c^{*}$ & & \\
\hline M. aurum & & $b^{*}$ & $c^{*}$ & & \\
\hline M. thermoresistibile & & $\mathrm{b}$ & $\mathrm{C}$ & $\mathrm{d}$ & \\
\hline$M$. chitae & & $\mathrm{b}$ & $\mathrm{C}$ & $\mathrm{d}$ & \\
\hline$M$. fortuitum & $\mathbf{a}$ & & & & \\
\hline $\begin{array}{l}\text { M. chelonei subsp. } \\
\text { chelonei }\end{array}$ & a & $b^{*}$ & & & $\mathrm{E}$ \\
\hline $\begin{array}{l}\text { M. chelonei subsp. } \\
\text { abscessus }\end{array}$ & a & & & & $\mathbf{E}$ \\
\hline$M$. flavescens & a & $b^{*}$ & $\mathrm{C}^{*}$ & & e \\
\hline
\end{tabular}

a Spot a, $R_{f} 0.14$ to 0.15 ; spot b, $R_{f} 0.25$ to 0.27 ; spot c, $R_{f}$ 0.39 to 0.43 ; spot d, $R_{f} 0.56$ to 0.59 ; spot e, $R_{f} 0.98$ to 1.00 . Spots indicated with a capital letter were the most prominently radioactive; for those indicated with an asterisk, the spots may be absent in one of three or in one or two of five strains tested. $M$. intracellulare strains 13001 and 13083 lack spot e and show no marked spot. $M$. nonchromogenicum strain 09003 lacks spot d. $M$. novum strain 24021 lacks spots a and d. $M$. marianum (M. scrofulaceum) strain 12107 lacks spots b and c. $M$. gordonae strain T-12177 shows a, b, c and e; strain T-12109 lacks spot c; and strain T-12110 lacks spot e and shows a small spot a. $M$. phlei strain 14001 lacks spot a. $\boldsymbol{M}$. vaccae strain 21011 lacks spot c. $\boldsymbol{M}$. aurum strain 15001 lacks spot b, and strain 15006 lacks spot c. $M$. fortuitum strains 18001 and 18109 show spots b and c. M. chelonei subsp. chelonei strains 19003 and 19010 lack spot b. $M$. chelonei subsp. abscessus strain 22014 shows spot b. $M$. flavescens strain 33001 lacks spots $b$ and $c$.

Strain T-12109 showed three spots, a, b, and e (Fig. 5A); strain T-12110 showed three spots, a, b, and c (Fig. 5C); and strain T-12177 showed four spots, a, b, c, and e. The results suggest that $M$. gordonae may be more heterogenous than other species.

Strains of $M$. intracellulare showed the same pattern (Fig. 5A). (It was very similar to that of $M$. avium [Fig. 2].) All three strains of M. terrae (Fig. 5E) and three strains of M. triviale (Fig. $5 \mathrm{~F})$ showed the same pattern, suggesting that these two species may be identical. Strains of $M$. novum (Fig. 5D) showed a pattern slightly different from that of $M$. terrae and $M$. triviale. Among nonpathogenic group III mycobacteria, the pattern for M. nonchromogenicum (Fig. 2A, $\mathrm{B}, \mathrm{C})$ could be distinguished from those of the other three, $M$. novum, $M$. terrae and $M$. triviale (Fig. 5D, E, F). However, the patterns of these four species showed some similarity. The patterns of rapidly growing mycobacteria are shown in Fig. 6 and 7. Usually, strains belonging to the same species showed the same pattern. However, three strains of $M$. aurum showed two spots and two strains showed only one.

$M$. thermoresistibile and $M$. chitae showed similar patterns, although these two species differ distinctly from each other in their phenetic characters (29). Four strains of $M$. flavescens showed four spots, whereas one strain showed two spots. Two subspecies of $M$. chelonei differed slightly in their patterns (Fig. $6)$.

\section{DISCUSSION}

The purpose of this study was to investigate the possibility of using TLC of the lipid fraction for differentiation among mycobacterial species. The ethyl ether-ethanol extraction method was chosen to simplify the procedure, although it might be insufficient for extraction of all lipids. This method gives results which may be useful for differentiation among certain mycobacterial species. We do not propose to investigate the method in greater depth. The information may be of use to others for further research, the possibilities of which are illustrated by the following. Both $M$. kansasii and $M$. marinum showed three common spots, but the former was differentiated from the latter by the presence of a fourth prominent spot (Fig. 4; Table 3). $M$. avium and $M$. intracellulare showed the same pattern (Fig. 2; Fig. 5). These two were considered to belong to the same species by the IWGMT (18).

In an IWGMT study, $M$. nonchromogenicum and $M$. terrae were considered to be closely related but of two different species (18). The results of our study suggest that these are differentiable by their patterns, although the patterns are of considerable similarity. Although $M$. novum was considered to be a synonym of $M$. terrae in an IWGMT study (18), these two showed slightly different patterns (Fig. 5). M. terrae and M. triviale showed the same pattern (Fig. 5). $M$. marianum ( $M$. scrofulaceum) and $M$. gordonae appear relatively heterogeneous with respect to their patterns, but these were distinguishable from the others.

Among rapidly growing mycobacteria, $M$. phlei and M. smegmatis showed characteristic patterns (Fig. 6). The patterns of $M$. chitae and $M$. thermoresistibile were similar to each other but different from those of the others (Fig. 6 

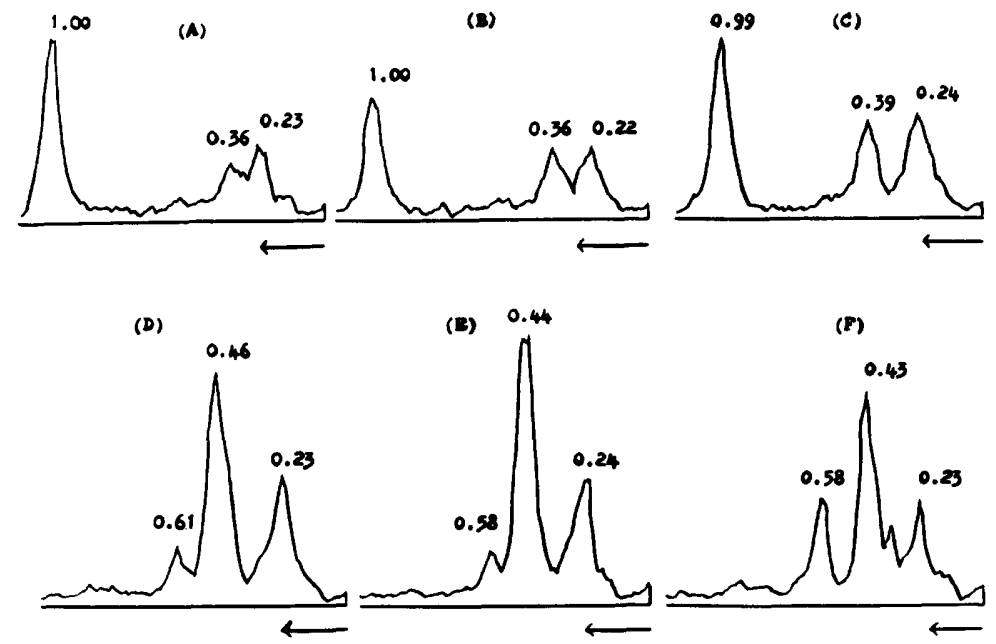

Fig. 1. Radioactive spots in thin-layer chromatogram of ethyl ether-ethanol-soluble fraction of $M$. nonchromogenicum (strain 09003) and $M$. chitae (strain 31003). (A) M. nonchromogenicum 09003 (a 21-day-old culture). (B) M. nonchromogenicum 09003 (a 14-day-old culture). (C) $M$. nonchromogenicum 09003 (a 7-day-old culture). (D) M. chitae 31003 (a 14-day-old culture). (E) M. chitae 31003 (a 7-day-old culture). (F) $M$. chitae 31003 (a 3-day-old culture). Cultures of various ages (days) were incubated with $\left[{ }^{35}\right.$ S] methionine for $20 \mathrm{~h}$, and their ethyl ether-ethanol-soluble fractions were subjected to TLC.

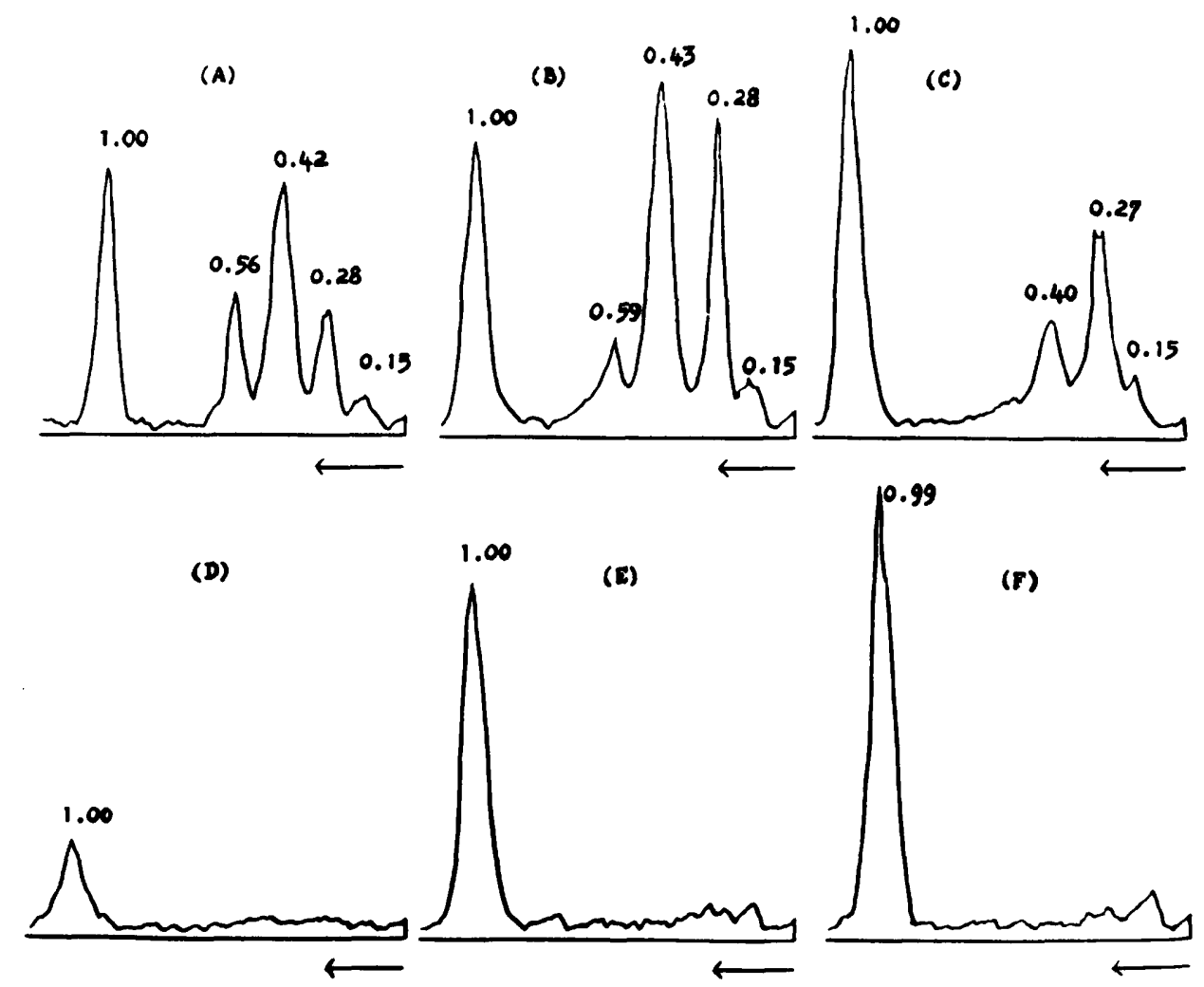

FIG. 2. Radioactive spots in thin-layer chromatogram of ethyl ether-ethanol-soluble fraction of three strains of $M$. nonchromogenicum and three strains of $M$. avium. (A) $M$. nonchromogenicum 09033 . (B) $M$. nonchromogenicum 09023. (C) $M$. nonchromogenicum 09003. (D) M. avium 11017. (E) M. avium 11016. (F) $M$. avium strain 11020 . 
(A)

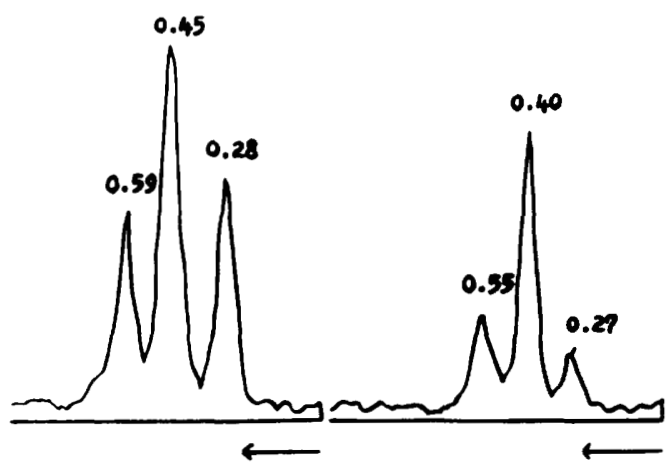

(B)

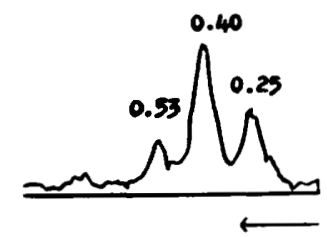

FiG. 3. Radioactive spots in thin-layer chromatogram of ethyl ether-ethanol-soluble fraction of three strains of $M$. thermoresistible. (A) M. thermoresistible 01002. (B) M. thermoresistible 01030. (C) M. thermoresistible 01028 .

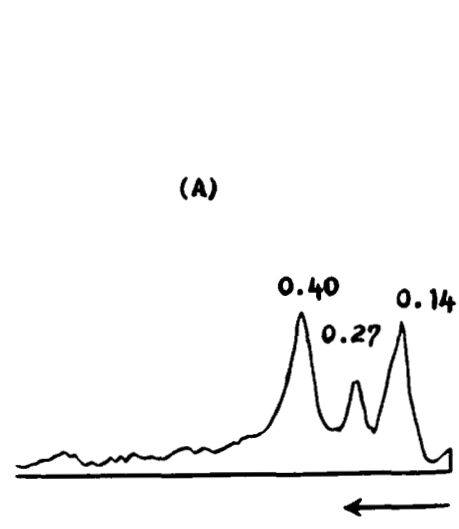

(C)
(B)

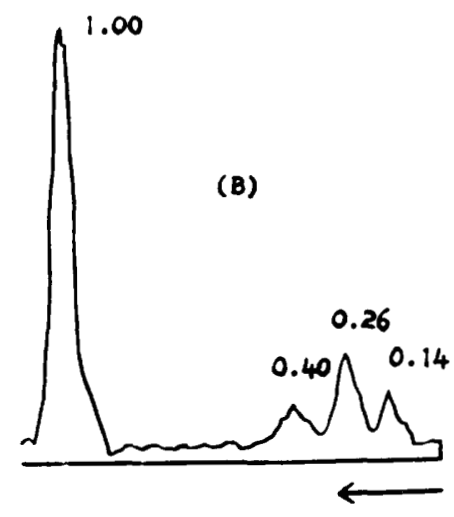

(D)

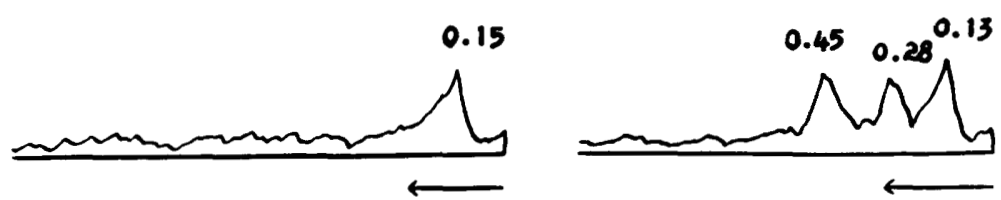

Fig. 4. Radioactive spots in thin-layer chromatogram of ethyl ether-ethanol-soluble fraction of $M$. kansasii, $M$. marinum, and $M$. marianum (M. scrofulaceum). (A) M. marinum 08010. (B) M. kansasii 07001. (C) $M$. marianum (M. scrofulaceum) 12107. (D) M. marianum (M. scrofulaceum) 12108. 


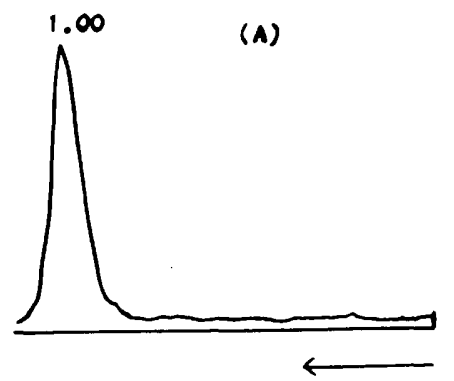

0.23

(D)

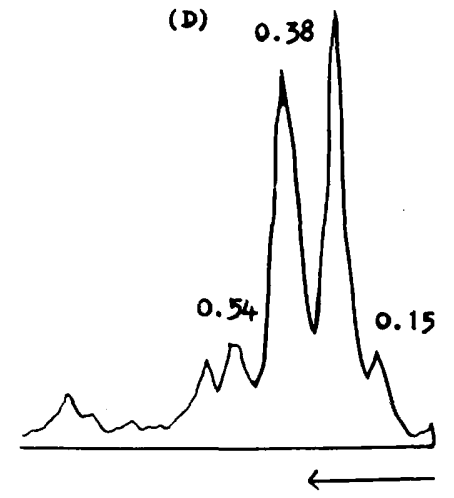

(B)

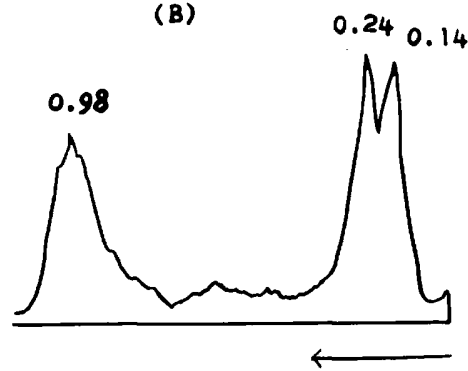

(E)
(C)

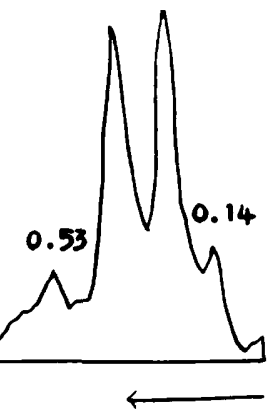

(F)

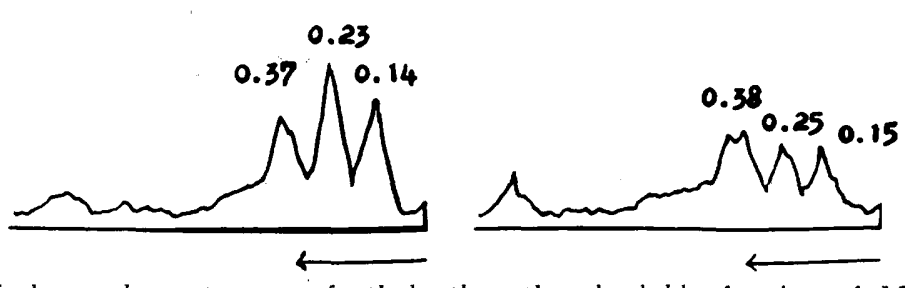

FIG. 5. Radioactive spots in thin-layer chromatogram of ethyl ether-ethanol-soluble fraction of $M$. intracellulare, $M$. gordonae, $M$. novum, $M$. terrae, and $M$. triviale. $(A) M$. intracellulare $13082 .(B) M$. gordonae T-12109. (C) M. gordonae T-12110. (D) M. novum 24018. (E) M. terrae 38013. (F) M. triviale 37003.

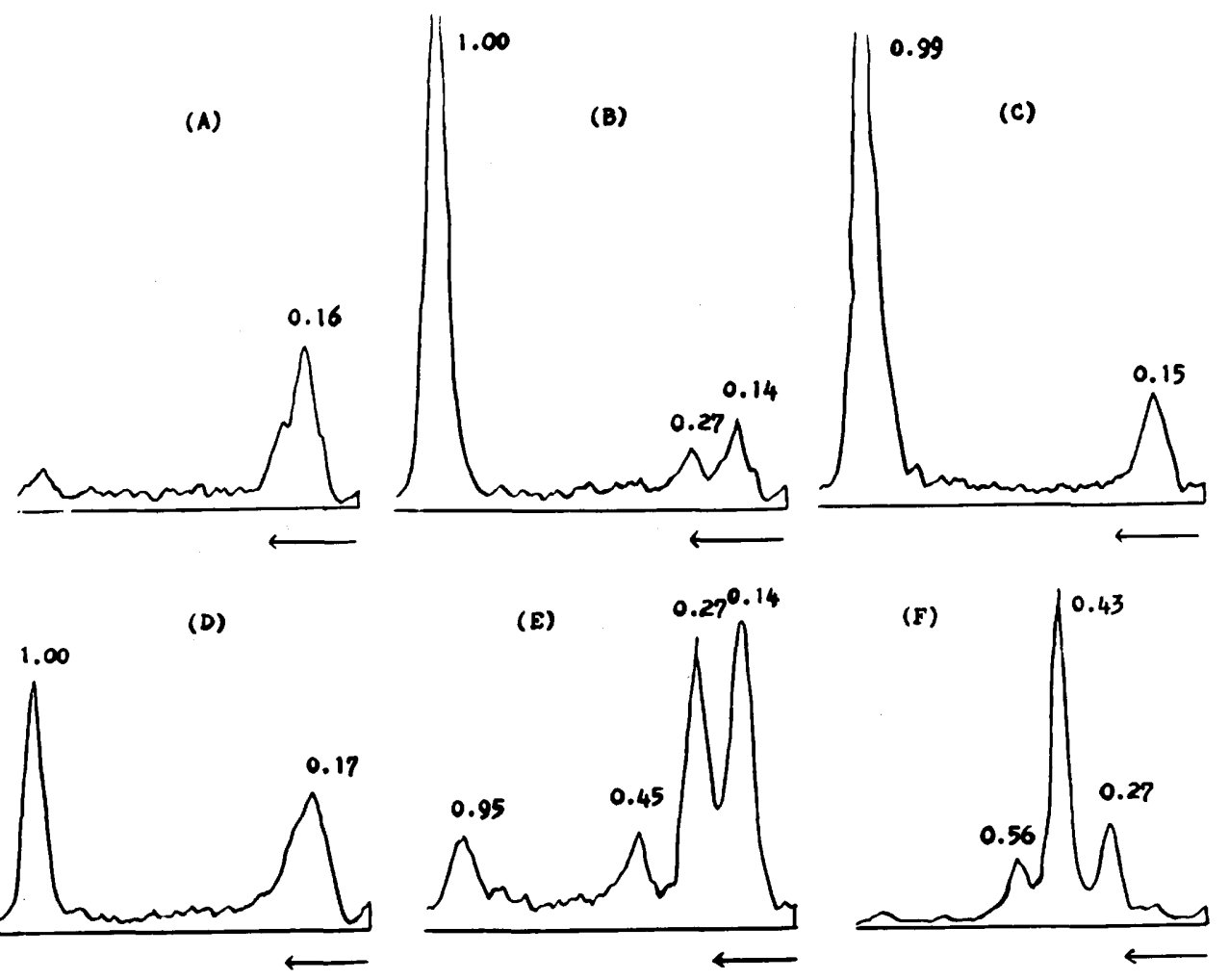

FIG. 6. Radioactive spots in thin-layer chromatogram of ethyl ether-ethanol-soluble fraction of $M$. fortuitum, $M$. chelonei subsp. chelonei, $M$. chelonei subsp. abscessus, $M$. smegmatis, $M$. phlei, and $M$. thermoresistible. (A) M. fortuitum 18104. (B) M. chelonei subsp. chelonei 19002. (C) M. chelonei subsp. abscessus 22015. (D) M. smegmatis 17027. (E) M. phlei 14022. (F) M. thermoresistible 01039. 


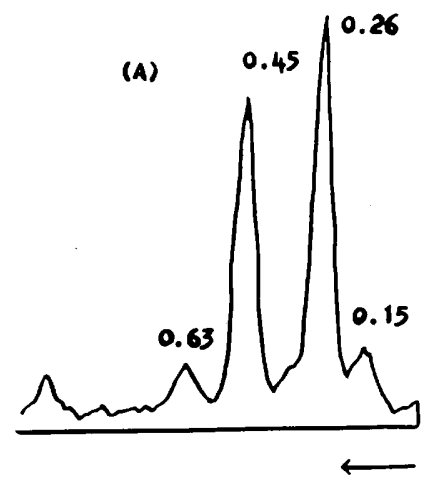

(D)

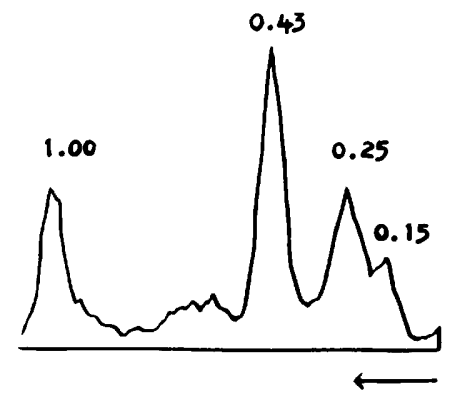

(B)

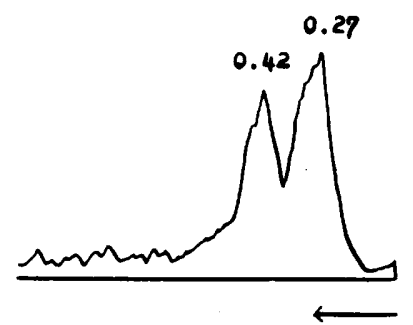

(5)

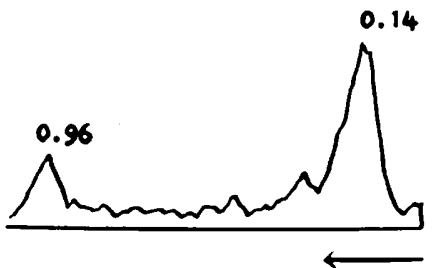

(c)

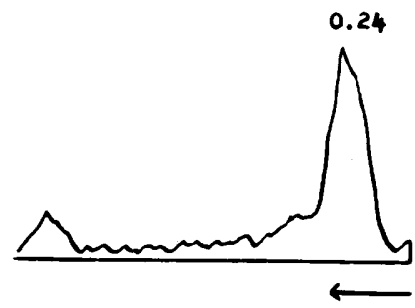

Fig. 7. Radioactive spots in thin-layer chromatogram of ethyl ether-ethanol-soluble fraction of $M$. vaccae, $M$. aurum, $M$. flavescens, and $M$. chitae. (A) M. vaccae 21009. (B) M. aurum 15001. (C) M. aurum 15006. (D) M. flavescens 33004. (E) M. flavescens 33001. (F) M. chitae 31003.

and 7). Two subspecies of $M$. chelonei showed slightly different patterns (Fig. 6). M. vaccae and $M$. aurum showed similar patterns (Fig. 7), but the type strain of $M$. aurum (15006; ATCC 23366) lacked one spot.

Strains identified as $M$. flavescens seemed to be heterogenous with respect to the pattern (Fig. 7). Four strains isolated in Japan (Table 1) had once been identified as $M$. gallinarum (32) and later were identified as $M$. flavescens (Tsukamura, personal communication to the IWGMT, 1973). These strains had a different pattern from that of $M$. flavescens (type strain ATCC 14474). Phenetically, there are few differences between $M$. flavescens and $M$. gallinarum $(30,32)$.

\section{REPRINT REQUESTS}

Address reprint requests to: Dr. M. Tsukamura, National Sanatorium Chubu Chest Hospital, Obu, Aichi, Japan 474.

\section{LITERATURE CITED}

1. Aronson, J. D. 1926. Spontaneous tuberculosis in soft water fish. J. Infect. Dis. 39:315-320.

2. Bergey, D. H., F. C. Harrison, R. S. Breed, B. W. Hammer, and F. M. Huntoon. 1923. Bergey's manual of determinative bacteriology, 1st ed., p. 376. The Williams \& Wilkins Co., Baltimore. (Cited from Index
Bergeyana, 1966 [5].)

3. Bojalil, L. F., J. Cerbón, and A. Trujillo. 1962. Adansonian classification of mycobacteria. J. Gen. Microbiol. 28:333-346.

4. Bönicke, R., and S. E. Juhasz. 1964. Beschreibung der neuen Species Mycobacterium vaccae $\mathrm{n}$. sp. Zentralbl. Bakteriol. Parasitenkd. Infektionskr. Hyg. Abt. 1 Orig. Reihe A 192:133-135.

5. Buchanan, R. E., J. G. Holt, and E. F. Lessel, Jr. (ed.). 1966. Index Bergeyana, p. 1-1472. The Williams \& Wilkins Co., Baltimore.

6. Chester, F. D. 1901. A manual of determinative bacteriology, p. 1-401 (p. 356), Macmillan, New York. (Cited from Index Bergeyana, 1966 [5].)

7. Da Costa Cruz, J. 1938. "Mycobacterium fortuitum" un nuovo bacilo acidoresistante patogenico para o homen. Acta Med. (Rio de Janeiro) 1:298-301.

8. Hauduroy, P. 1955. Derniers aspects du monde des mycobactéries, p. 73. Masson et Cie, Paris.

9. Jenkins, P. A., J. Marks, and W. B. Schaefer. 1971. Lipid chromatography and seroagglutination in the classification of rapidly growing mycobacteria. Am. Rev. Respir. Dis. 103:179-187.

10. Jenkins, P. A., J. Marks, and W. B. Schaefer. 1972. Thin-layer chromatography of mycobacterial lipids as an aid to classification: the scotochromogenic mycobacteria, including $M y c o b a c t e r i u m$ scrofulaceum, $M$. xenopi, $M$. aquae, $M$. gordonae, $M$. flavescens. Tubercle 53:118-127.

11. Kubica, G. P., I. Baess, R. E. Gordon, P. A. Jenkins, J. B. G. Kwapinski, C. McDurmont, S. R. Pattyn, H. Saito, V. Silcox, J. L. Stanford, K. Takeya, and M. Tsukamura. 1972. A co-operative numerical analysis of rapidly growing mycobacteria. J. Gen. Microbiol. 73:55-70. 
12. Kubica, G. P., V. A. Silcox, J. O. Kilburn, R. W. Smithwick, R. E. Beam, W. D. Jones, and K. D. Stottmeier. 1970. Differential identification of mycobacteria. VI. Mycobacterium triviale Kubica sp. nov. Int. J. Syst. Bacteriol, 20:161-174.

13. Lanéelle, M. A., J. Asselineau, and G. Castelnuovo. 1969 Études sur les mycobactéries et les nocardiae. IV. Composition des lipides de Mycobacterium rhodochrous, $M$. pellegrino, sp., et de nocardiae. Ann. Inst. Pasteur Paris 108:69-82.

14. Lechevalier, M. P., A. C. Horan, and H. Lechevalier 1971. Lipid composition in the classification of nocardiae and mycobacteria. J. Bacteriol. 105:313-318.

15. Lehmann, K. B., and R. O. Neumann. 1899. Lehmann's Medizinischen Handatlanten. X. Atlas und Grundriss der Bakteriologie und Lehrbuch der speziellen bakteriologischen Diagnostik. 2:1-497 (p. 403, M. smegmatis; p. 411, M. phlei) (Cited from Index Bergeyana, 1966 [5].)

16. Marks, J., P. A. Jenkins, and W. B. Schaefer. 1971. Thin-layer chromatography of mycobacterial lipids as an aid to classification: technical improvements: $\boldsymbol{M} \boldsymbol{y}$ cobacterium avium, $M$. intracellulare (Battey bacilli). Tubercle 52:219-225.

17. Marks, J., and T. Szulga. 1965. Thin-layer chromatography of mycobacteria lipids as an aid to classification: technical procedures; Mycobacterium fortuitum. Tubercle 46:400-411.

18. Meissner, G., K. H. Schröder, G. E. Amadio, W. Anz, S. Chaparas, H. W. B. Engel, P. A. Jenkins, W. Käppler, H. H. Kleeberg, E. Kubala, M. Kubin, D. Lauterbach, A. Lind, M. Magnusson, Z. Mikova, S. R. Pattyn, W. B. Schaefer, J. L. Stanford, M. Tsukamura, L. G. Wayne, I. Willers, and E. Wolinsky. 1974. A co-operative numerical analysis of nonscoto- and nonphotochromogenic slowly growing mycobacteria. J. Gen. Microbiol. 83:207-235.

19. Moore, M., and J. B. Frerichs. 1953. An unusual acid-fast infection of the knee with subcutaneous, abscess-like lesions of the gluteal region. Report of a case with a study of the organism, Mycobacterium abscessus. J. Invest. Dermatol. 20:133-169.

20. Runyon, E. H. 1967. Mycobacterium intracellulare. Am. Rev. Respir. Dis. 95:861-865.

21. Smith, D. W., H. M. Randall, M. M. Gastambide-Odier, and A. L. Koevoet. 1957. The characterization of mycobacterial strains by the composition of their lipid extracts. Ann. N.Y. Acad. Sci. 69:145-157.

22. Smith, D. W., H. M. Randall, A. P. Maclennan, R. K. Putney, and S. V. Rao. 1960. Detection of specific lipids in mycobacteria by infrared spectroscopy. J. Bacteriol. 79:217-229.

23. Suzanne, M., and G. Penso. 1953. Sulla identità specifica del cosidetto "Ceppo Chauvirè," Mycobacterium marianum n. $s p$. Riassunto delle Communicazione del VI. Congresso Internazionale di Microbiologia (Rome) 2:655-656.

24. Szulga, T., P. A. Jenkins, and J. Marks. 1966. Thin-layer chromatography of mycobacterial lipids as an aid to classification: Mycobacterium kansasii; and Mycobacterium marinum (balnei). Tubercle 47:130-136.

25. Tsukamura, M. 1965. A group of mycobacteria from soil sources resembling nonphotochromogens (Group III). A description of Mycobacterium nonchromogenicum. Med. Biol. (Tokyo) 71:110-113.

26. Tsukamura, M. 1966. Adansonian classification of mycobacteria. J. Gen. Microbiol. 45:253-273.

27. Tsukamura, M. 1967. Two types of slowly growing, nonphotochromogenic mycobacteria obtained from soil by the mouse passage method: Mycobacterium terrae and Mycobacterium novum. Jpn. J. Microbiol. 11:163-172.

28. Tsukamura, M. 1967. Mycobacterium chitae: a new species. Jpn. J. Microbiol. 11:43-47.

29. Tsukamura, M. 1967. Identification of mycobacteria. Tubercle 48:311-338

30. Tsukamura, M. 1968. Classification of scotochromogenic mycobacteria. Jpn. J. Microbiol. 12:63-75.

31. Tsukamura, M., S. Mizuno, and S. Tsukamura. 1966. Uptake of ${ }^{35} \mathrm{~S}$-methionine by various mycobacteria. Med. Biol. (Tokyo) 73:64-66.

32. Tsukamura, M., S. Tsukamura, S. Mizuno, and $\mathbf{H}$. Toyama. 1967. Bacteriological studies on atypical mycobacteria isolated in Japan. Report III. A comparison between pathogenic scotochromogens and soil scotochromogens (Origin of pathogenic scotochromogens) Kekkaku (Tokyo) 42:15-21.

33. Walker, R. W. W. L. Mallmann, and J. R. Brunner. 1967. Type-specific lipids of mycobacteria. Am. Rev. Respir Dis. 95:1065-1067.

34. Wayne, L. G. 1966. Classification and identification of mycobacteria. III. Species within Group III. Am. Rev. Respir. Dis. 93:919-928.

35. Wayne, L. G., T. M. Dietz, C. Gernez-Rieux, P. A. Jenkins, W. Käppler, G. P. Kubica, J. B. G. Kwapinski, G. Meissner, S. R. Pattyn, E. H. Runyon, K. H. Schröder, V. A. Silcox, A. Tacquet, M. Tsukamura and E. Wolinsky. 1971. A co-operative numerical analysis of scotochromogenic slowly growing mycobacteria. J. Gen. Microbiol. 66:255-276. 